\title{
Rothia aeria sp. nov., Rhodococcus baikonurensis sp. nov. and Arthrobacter russicus sp. nov., isolated from air in the Russian space laboratory Mir
}

\author{
Ying Li, ${ }^{1}$ Yoshiaki Kawamura, ${ }^{1}$ Nagatoshi Fujiwara, ${ }^{2}$ Takashi Naka, ${ }^{2}$ \\ Hongsheng Liu, ${ }^{1}$ Xinxiang Huang, ${ }^{1}$ Kazuo Kobayashi ${ }^{2}$ and Takayuki Ezaki ${ }^{1}$ \\ ${ }^{1}$ Department of Microbiology - Bioinformatics, Regeneration and Advanced Medical Science, \\ Gifu University, Graduate School of Medicine, Tsukasa-machi 40, Gifu 500-8705, Japan \\ ${ }^{2}$ Department of Bacteriology, Osaka City University, Medical School, Abeno-ku, \\ Osaka 545-8585, Japan
}

Correspondence

Takayuki Ezaki

tezaki@cc.gifu-u.ac.jp
Four Gram-positive bacteria, strains $A 1-17 B^{\top}, A 1-22^{\top}, A 1-3^{\top}$ and $A 1-8$, isolated from the air in the Russian space laboratory Mir, were subjected to a polyphasic taxonomic study. Phylogenetic analysis of the bacteria based on their $16 \mathrm{~S}$ rDNA sequence showed that they belong to the genera Rothia $\left(\mathrm{A} 1-17 \mathrm{~B}^{\top}\right)$, Rhodococcus $\left(\mathrm{A} 1-22^{\top}\right)$ and Arthrobacter $\left(\mathrm{A} 1-3^{\top}\right.$ and $\left.\mathrm{A} 1-8\right)$.

Morphological, physiological, chemotaxonomic and genomic characteristics supported the assignments of these strains to these genera, but they could not be classified as any existing species within each respective genus. 16S rDNA similarity values between strain $A 1-17 B^{\top}$ and its neighbours, Rothia dentocariosa genomovar II, Rothia dentocariosa, Rothia mucilaginosa and Rothia nasimurium, were respectively 99.8, 98.0, 96.4 and 95.4\%. Polyphasic taxonomic evidence indicated that strain $A 1-17 B^{\top}$ should be categorized together with the unofficially named Rothia dentocariosa genomovar II, but clearly differentiated them from the established species of the genus Rothia. Strain A1-22 $2^{\top}$ formed a coherent cluster with Rhodococcus erythropolis, Rhodococcus globerulus, Rhodococcus marinonascens and Rhodococcus percolatus in 16S rDNA sequence analysis, but DNA-DNA relatedness values were only $45 \cdot 5,35 \cdot 3,18.9$ and $21.9 \%$. Strains $A 1-3^{\top}$ and $A 1-8$ shared $99 \cdot 9 \% 16 \mathrm{~S}$ rDNA sequence similarity, and strain $A 1-3^{\top}$ showed the highest level of $16 \mathrm{~S}$ rDNA similarity, 96.6\%, to Arthrobacter polychromogenes. Contrasting biochemical characteristics were also identified. Finally, as a result of the polyphasic taxonomic study, three of the strains are proposed as type strains of novel species: Rothia aeria sp. nov. $\left(\mathrm{A} 1-17 \mathrm{~B}^{\top}=\mathrm{GTC} 867^{\top}=\mathrm{JCM} 11412^{\top}=\mathrm{DSM} 14556^{\top}\right)$, Rhodococcus baikonurensis sp. nov. $\left(A 1-22^{\top}=\right.$ GTC $\left.1041^{\top}=J C M 11411^{\top}=\mathrm{DSM} 44587^{\top}\right)$ and Arthrobacter russicus sp. nov. $\left(A 1-3^{\top}=\right.$ GTC $\left.863^{\top}=J C M 11414^{\top}=D S M 14555^{\top}\right)$.

\section{INTRODUCTION}

Decelle \& Taylor (1976) reported that in-flight crosscontamination and build-up of pathogens were noted in the Apollo space station. The space station is a special environment with reduced gravity, and crews must live in a completely closed environment for extended periods of time. Because of the many unfavourable effects of space flight and mental stress, astronauts may suffer weakened

Published online ahead of print on 12 December 2003 as DOI 10.1099/ijs.0.02828-0.

The GenBank/EMBL/DDBJ accession numbers for the $16 \mathrm{~S}$ rDNA sequences of Arthrobacter russicus sp. nov. A1-3 ${ }^{\top}$, Rothia aeria sp. nov.

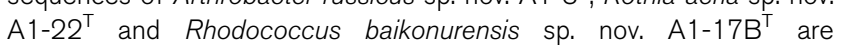
AB071950-AB071952. immunocompetence and may even become infected by opportunistic pathogens (Criswell-Hudak, 1991). It is therefore essential to understand and control the microbial population in these environments. Bacteria were isolated from air and condensation water samples from the Russian space station Mir in 1997 and the bacterial population was analysed. Previous investigation had shown that bacteria from air samples were mainly Gram-positive, and most of the strains were opportunistic pathogens (Kawamura et al., 2001). A polyphasic taxonomic study showed that seven strains, belonging to six species, failed to match any established species. Three Gram-negative species of these isolates have been described elsewhere (Li et al., 2003, 2004). The taxonomic status of the four Gram-positive isolates was investigated in detail here. 
Gram-positive bacteria have stronger resistance to dry conditions than do Gram-negative bacteria because of their firm cell-wall structure (Neidhardt, 1990). All four Gram-positive strains were isolated from air samples. These bacteria, drifting in the air of the space station, may become an infectious source and threaten the health of space-station astronauts, especially when astronauts have weakened immunocompetence. The four Gram-positive isolates were affiliated with the genera Rothia, Rhodococcus and Arthrobacter. As a result of polyphasic taxonomic study, these isolates should now be classified as the novel species Rothia aeria sp. nov., Rhodococcus baikonurensis sp. nov. and Arthrobacter russicus sp. nov.

\section{METHODS}

Sample collection, morphology, physiology and DNA extraction. Air samples from the living environment of the Mir space station were collected and filtered and filters were stored as described by $\mathrm{Li}$ et al. (2004). After transfer to the laboratory, samples were cultured as described by $\mathrm{Li}$ et al. (2004) with incubation at $30^{\circ} \mathrm{C}$. Biochemical characterization of the isolates was performed using API CORYNE (API bioMérieux) and Biolog GP2 MicroPlate assay (Biolog). Oxidase activity was determined with oxidase test strips (Eiken Chemical). DNA was extracted as described by Ezaki et al. (1994).

Chemotaxonomic characterization. Diamino acids were analysed by TLC as described by Kawamura et al. (1995). Other cell-wall amino acid analysis was performed as described by Komagata \& Suzuki (1987). Briefly, bacteria were suspended in $10 \mathrm{ml} 10 \%$ trichloroacetic acid (w/v) and boiled for $30 \mathrm{~min}$. The lysed bacteria were separated by centrifugation and the precipitate was then washed twice with distilled water and concentrated down at 10000 r.p.m. for $10 \mathrm{~min}$, resuspended in $10 \mathrm{ml}$ PBS $(0 \cdot 145 \mathrm{M}$ sodium chloride, $5 \mathrm{mM}$ monobasic sodium phosphate, $8 \mathrm{mM}$ dibasic sodium phosphate, $\mathrm{pH} \mathrm{7.9)}$ containing trypsin $\left(2 \mathrm{mg} \mathrm{ml}^{-1}\right)$ and incubated at $37^{\circ} \mathrm{C}$ for $3 \mathrm{~h}$. The precipitate was collected after centrifugation and washed twice with distilled water. It was then freezedried. Approximately $1 \mathrm{mg}$ cell wall was hydrolysed for $18 \mathrm{~h}$ at $100{ }^{\circ} \mathrm{C}$ in $1 \mathrm{ml} 6 \mathrm{M} \mathrm{HCl}$. The hydrolysate was dried in a rotary evaporator and dissolved in $100 \mu \mathrm{l}$ distilled water. Amino acids were mixed with $20 \mu \mathrm{l}$ phenyl isothiocyanate solution (Wako) (ethanol/ distilled water/trimethylamine/phenyl isothiocyanate, $7: 1: 1: 1$ by vol.) at room temperature for $20 \mathrm{~min}$ and analysed by HPLC (Hitachi UV detector L-7400) equipped with a Wakopak WS-PTC $(4 \times 200 \mathrm{~mm})$ column.

Cellular fatty-acid compositions were measured using the Sherlock Microbial Identification system (MIDI) and method as described by Kosako et al. (2000). Mycolic acids were extracted and analysed as described by Nishiuchi et al. (1999). Polar lipids were identified as described by Minnikin et al. (1984). Isoprenoid quinone analysis was performed by reverse-phase TLC as described by Collins et al. (1977) and Yano et al. (1987).

Analysis of 16S rDNA sequence and DNA base composition. The 16S rRNA gene was amplified with universal primers (forward: 5'-AGAGTTTGATCMTGGCTCAG-3'; reverse: 5'-ACGGGCGGTGTGTRC- $3^{\prime}$ ) and the PCR products for all isolates were sequenced in both directions. The sequences were analysed and trees generated as described by Li et al. (2004).

The G $+\mathrm{C}$ content was measured by HPLC as described by Ezaki et al. (1990). Escherichia coli was used as a standard ( $\mathrm{G}+\mathrm{C}$ content $51 \cdot 19 \mathrm{~mol} \%)$.
DNA-DNA hybridization. Quantitative microplate DNA-DNA hybridization for selected strains was carried out as described by Ezaki et al. (1988, 1989). Hybridization experiments were carried out under optimal and stringent temperatures calculated from melting temperatures $\left(T_{\mathrm{m}}\right)$ based on the $\mathrm{G}+\mathrm{C}$ content of each test strain.

\section{RESULTS AND DISCUSSION}

\section{Strain A1-17B}

The genus Rothia was proposed by Georg \& Brown (1967) with Rothia dentocariosa as the type species. The phenotypic heterogeneity within the species has long been known (Lesher et al., 1974; Schofield \& Schaal, 1981; Fotos et al., 1984), and the existence of a second genomovar was described by Kronvall et al. (1998). However, Rothia dentocariosa was recognized as the only species of the genus until Collins et al. (2000) described a novel species (Rothia nasimurium) and reclassified Stomatococcus mucilaginosus as Rothia mucilaginosa. Fan et al. (2002) proposed a further member, Rothia amarae.

Strain $\mathrm{A} 1-17 \mathrm{~B}^{\mathrm{T}}$, isolated from air samples in the Russian space station Mir, formed a distinct phylogenetic subline and exhibited a specific association with genus Rothia (Fig. 1). 16S rDNA sequence similarity values between A1$17 \mathrm{~B}^{\mathrm{T}}$ and its neighbours, Rothia dentocariosa genomovar II, Rothia dentocariosa, Rothia mucilaginosa, Rothia amarae and Rothia nasimurium, were respectively $99 \cdot 8,98 \cdot 0,96 \cdot 4$,

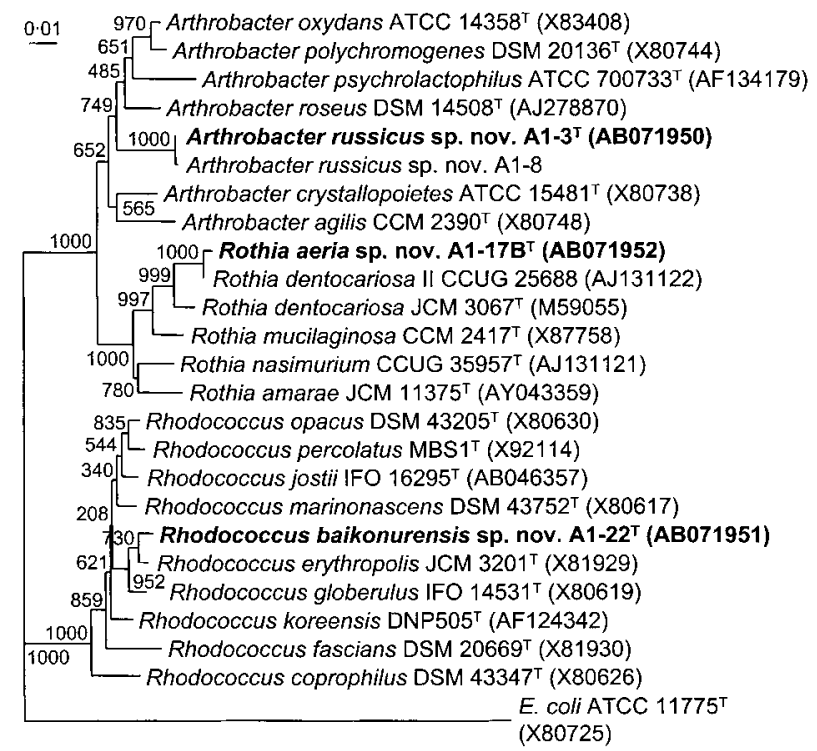

Fig. 1. Phylogenetic position of four Gram-positive isolates from the Mir space station and selected members of the genera Arthrobacter, Rothia and Rhodococcus based on $16 \mathrm{~S}$ rDNA sequences. Distances were calculated by the neighbourjoining method. Numbers at branch points are bootstrap values (based on 1000 samplings). GenBank accession numbers are given. Bar, 0.01 estimated substitutions per nucleotide position. E. coli was used as an outgroup. 
96.0 and $95.4 \%$, as determined by CLUSTAL $\mathrm{W}$ analysis. Similarity values to other members of the family Micrococcaceae were less than $95.0 \%$. Phylogenetic data showed that strain $\mathrm{A} 1-17 \mathrm{~B}^{\mathrm{T}}$ is a member of the genus Rothia. The $\mathrm{G}+\mathrm{C}$ content is $57 \cdot 8 \mathrm{~mol} \%$, which is within the range of $47-59$ mol\% observed in the genus (Bergan \& Kocur, 1982; Gerencser \& Bowden, 1986). This strain also showed morphological similarity to members of the genus Rothia (Georg \& Brown, 1967) (see species description below).

TLC analysis indicated that the isolated strains did not contain diaminopimelic acid in the cell wall, which is consistent with Rothia dentocariosa (Georg \& Brown, 1967). HPLC analysis of the peptidoglycan showed that the amino acids glutamic acid, alanine and lysine occur in a molar ratio of $1: 3: 1$; these results suggest that the interpeptide bridge contains alanine and that the peptidoglycan type is A3 $\alpha$-type (Schleifer \& Kandler, 1972). The predominant isoprenoid quinone is menaquinone with seven isoprenoid units (MK-7), which is consistent with other related species in the genus Rothia (Table 1). Examination of the cellular fatty acids of $\mathrm{A} 1-17 \mathrm{~B}^{\mathrm{T}}$ revealed that the acids are predominantly of the iso- and anteisomethyl-branching types. This is also similar to the composition of other species of Rothia (Table 1). The predominant polar lipids were phosphatidylglycerol and cardiolipin, with phosphatidylinositol as a minor component.

Strain $\mathrm{A} 1-17 \mathrm{~B}^{\mathrm{T}}$ and Rothia dentocariosa genomovar II (CCUG 25688, CCUG 33543) showed the following common biochemical characteristics with Rothia dentocariosa and Rothia mucilaginosa: positive for nitrate reduction, pyrazinamidase, alanine-phenylalanine-proline arylamidase, $\alpha$-glucosidase and $\beta$-glucosidase activities, hydrolysis of aesculin and acid production from glucose, maltose and sucrose; negative for $\beta$-glucuronidase, $\beta$-galactosidase,

Table 1. Differential characteristics of Rothia aeria sp. nov. $A 1-17 \mathrm{~B}^{\top}$ and closely related species of the genus Rothia

Strains: 1, Rothia aeria sp. nov. A1-17B ${ }^{\mathrm{T}}$; 2, Rothia dentocariosa genomovar II CCUG 25688; 3, Rothia dentocariosa genomovar II CCUG 33543; 4, Rothia dentocariosa JCM 3067 ${ }^{\mathrm{T}}$; 5, Rothia mucilaginosa CCM $2417^{\mathrm{T}}$. Data for cellular fatty acids for reference stains are from Collins et al. (2000) and Fan et al. (2002). Strain A1-17B ${ }^{\mathrm{T}}$ also contains anteiso-13:0, 14:0 and iso-17:0 (each $<1 \%$ ). Rothia dentocariosa also contains 15:0 (2.2\%). w, Weakly positive; ND, not determined.

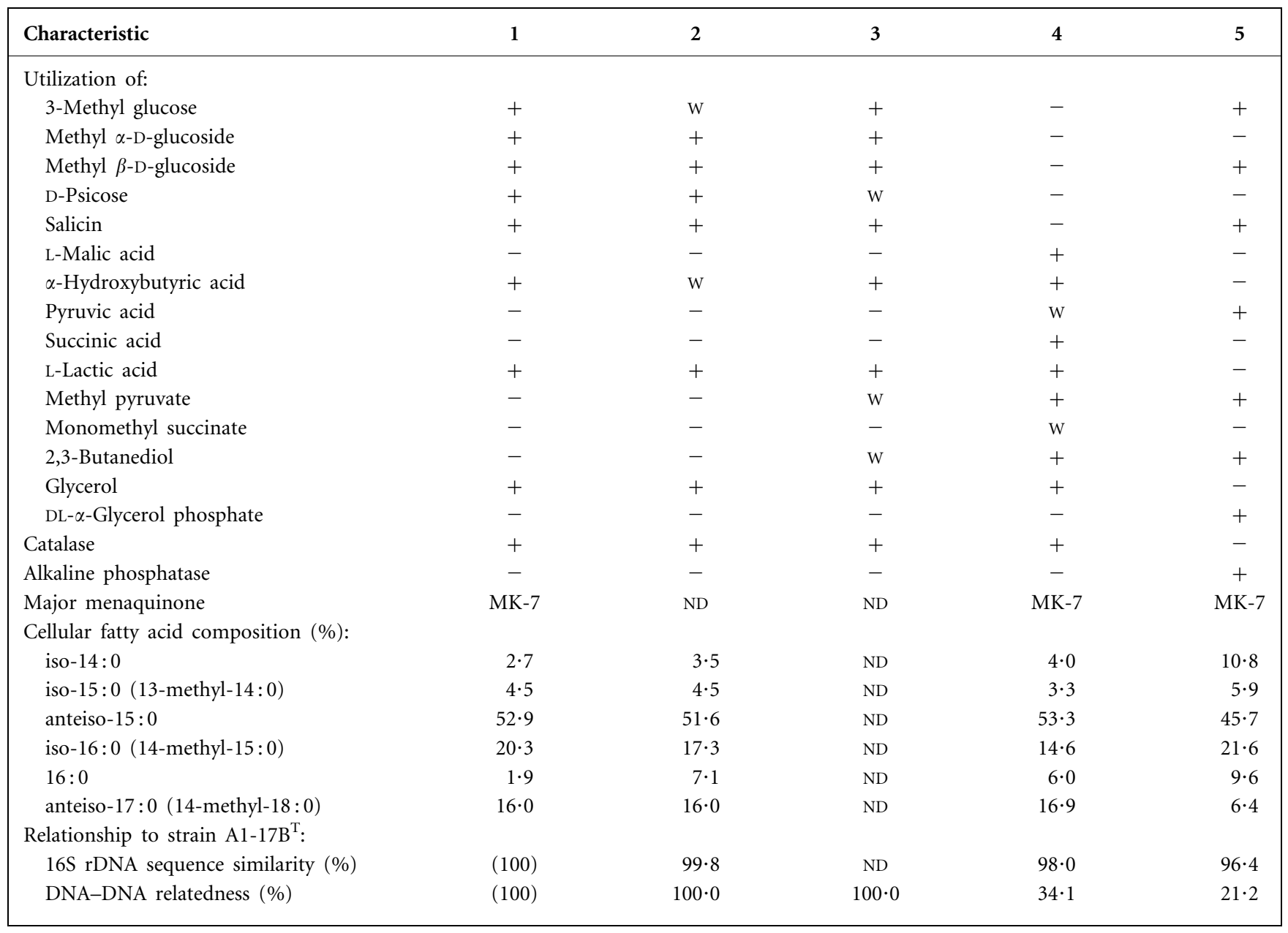


$N$-acetyl- $\beta$-glucosaminidase and urease activities and production of acid from ribose, xylose, mannitol, lactose and glycogen. These similar biochemical profiles support their relationship to these taxa. However, some common characteristics of strain $\mathrm{A} 1-17 \mathrm{~B}^{\mathrm{T}}$ and Rothia dentocariosa genomovar II differentiated them from Rothia dentocariosa and Rothia mucilaginosa (Table 1). The results of the Biolog GP2 assay for strain $\mathrm{A} 1-17 \mathrm{~B}^{\mathrm{T}}$ are summarized in Table 2.

DNA-DNA hybridization showed that strain $A 1-17 \mathrm{~B}^{\mathrm{T}}$ and Rothia dentocariosa genomovar II have $100 \%$ DNA relatedness, whereas they showed only $34 \cdot 1$ and $21 \cdot 2 \%$ relatedness with their related neighbours Rothia mucilaginosa and Rothia dentocariosa (Table 1), confirming that this strain represents a taxonomically independent species.

$16 \mathrm{~S}$ rDNA sequence similarity of $99 \cdot 8 \%$ and DNA-DNA relatedness of $100 \%$ between strain $\mathrm{A} 1-17 \mathrm{~B}^{\mathrm{T}}$ and Rothia dentocariosa genomovar II indicated that they belong to the same species. Kronvall et al. (1998) suggested the possibility that Rothia dentocariosa genomovar II is a novel species of the genus. However, Rothia dentocariosa genomovar II has not been formally named as it could not be distinguished from authentic Rothia dentocariosa using API systems (Kronvall et al., 1998). In this study, strain $\mathrm{A} 1-17 \mathrm{~B}^{\mathrm{T}}$, Rothia dentocariosa genomovar II and Rothia dentocariosa also showed the same biochemical characteristics using the API Coryne system, but the Biolog GP2 system clearly differentiated them biochemically from Rothia dentocariosa (Table 1). DNA hybridization data also supported strain $\mathrm{A} 1-17 \mathrm{~B}^{\mathrm{T}}$ and Rothia dentocariosa genomovar II as belonging to the same species and independent from other species of Rothia. Based on polyphasic taxonomic analysis, strain $\mathrm{A} 1-17 \mathrm{~B}^{\mathrm{T}}$ and Rothia dentocariosa genomovar II (strains CCUG 25688 and CCUG 33543) clearly merit classification as a novel species within the genus Rothia, Rothia aeria sp. nov.

\section{Strain A1-22 ${ }^{\mathbf{T}}$}

Sequence analysis by the FASTA search system on the DDBJ website showed that strain $\mathrm{A} 1-22^{\mathrm{T}}$ was phylogenetically most closely related to the genus Rhodococcus. The phylogenetic position of strain $\mathrm{A} 1-22^{\mathrm{T}}$ as analysed by CLUSTAL W software showed that it is closely related to Rhodococcus erythropolis, Rhodococcus globerulus, Rhodococcus marinonascens and Rhodococcus percolatus, with respective $16 \mathrm{~S}$ rDNA sequence similarities of $99 \cdot 2,98 \cdot 9,97 \cdot 6$ and $97 \cdot 0 \%$ (Fig. 1). Similarity values to other Rhodococcus species and species of other genera were less than $97 \%$ (data not shown). Phylogenetic analysis supported the affinity of strain A1-22 ${ }^{\mathrm{T}}$ to genus Rhodococcus.

Strain A $1-22^{\mathrm{T}}$ also showed similar phenotypic characteristics to Rhodococcus species (see species description below). Biochemically, strain A1-22 ${ }^{\mathrm{T}}$ showed catalase and urease activities, but not oxidase activity, and was able to hydrolyse aesculin but not arbutin. The results of the Biolog GP2 analysis are shown in Table 2. Although strain $\mathrm{A} 1-22^{\mathrm{T}}$ showed similar biochemical properties to its closest relative, Rhodococcus erythropolis, hydrolysis of arbutin and utilization of $m$-inositol enable them to be differentiated (Table 3).

TLC analysis of strain $\mathrm{A} 1-22^{\mathrm{T}}$ indicated that the strain contains meso-diaminopimelic acid as the major diamino acid in the cell wall, which is a feature of the genus Rhodococcus (Goodfellow, 1986). HPLC analysis of the peptidoglycan showed that glycine, alanine and diaminopimelic acid are present in a $1: 2: 1$ molar ratio. These results suggest that the peptidoglycan is Al $\gamma$-type, which is consistent with Rhodococcus fascians (Goodfellow, 1984). The predominant isoprenoid quinone is $\mathrm{MK}-8\left(\mathrm{H}_{2}\right)$, which is consistent with the closely related species of the genus Rhodococcus (Goodfellow, 1986).

The cellular fatty acid composition of strain $\mathrm{A} 1-22^{\mathrm{T}}$ was: $14: 0,5 \%$; cis- $16: 1,9 \%$; $16: 0,41 \%$; cis- $18: 1,18 \%, 18: 0$, $4 \%$, tuberculostearic acid (10-methyl-18:0), $22 \%$ (only components representing $\geqslant 1 \%$ of the total are reported). This composition is similar to that of some Rhodococcus species, but the strain can be differentiated from Rhodococcus erythropolis based on the content of 16:0 and 19:0 (22 and $10.9 \%$ in Rhodococcus erythropolis; Yoon et al., 2000). The number of carbons in mycolic acids varies from 22 to 90, compared with the genera Corynebacterium (22-28), Gordonia (48-66), Mycobacterium (66-90), Nocardia (46-60) and Rhodococcus (32-66) (Goodfellow, $1986,1992)$. The mycolic acid carbon chain of strain A1-22 ${ }^{\mathrm{T}}$ determined by GLC/MS was 32-42 atoms in length with three double bonds, consistent with the genus Rhodococcus, with zero to four double bonds (Goodfellow, 1986). The cellular phospholipids were phosphatidylethanolamine, cardiolipin, phosphatidylinositol and phosphatidylinositol mannosides, again consistent with the properties of the genus Rhodococcus (Goodfellow, 1986).

DNA-DNA relatedness values of strain A1- $22^{\mathrm{T}}$ with its closely related neighbours Rhodococcus erythropolis, Rhodococcus globerulus, Rhodococcus marinonascens and Rhodococcus percolatus were only $45 \cdot 5,35 \cdot 3,18 \cdot 9$ and $21 \cdot 9 \%$. All hybridization rates were below the suggested threshold value ( $70 \%$ ) (Grimont, 1999; Wayne et al., 1987), confirming that this strain represents a genetically independent species.

Based on polyphasic taxonomic results, strain $\mathrm{A} 1-22^{\mathrm{T}}$ is affiliated with the genus Rhodococcus. However, based on its biochemical properties and chemotaxonomic characteristics, strain $\mathrm{A} 1-22^{\mathrm{T}}$ is different from any established species of the genus. DNA-DNA hybridization data $(<70 \%)$ confirmed that strain $\mathrm{A} 1-22^{\mathrm{T}}$ taxonomically represents an independent species. Thus, we propose the name Rhodococcus baikonurensis sp. nov. for this organism.

\section{Strain $\mathbf{A} 1-\mathbf{3}^{\mathbf{T}}$}

Sequence analysis by the FASTA search system on the DDBJ website showed that strains $A 1-3^{\mathrm{T}}$ and $\mathrm{A} 1-8$ were phylogenetically most closely related to the genus 
Table 2. Results of Biolog GP2 assays

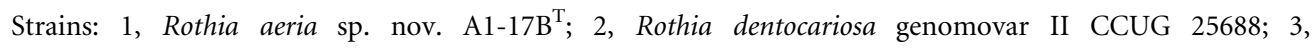
Rhodococcus baikonurensis sp. nov. A1-22 $2^{\mathrm{T}}$; Arthrobacter russicus sp. nov. A1-3 ${ }^{\mathrm{T}} ; 5$, A. russicus sp. nov. A1-8. W, Weakly positive. All strains reacted positive for $\alpha$-D-glucose, D-psicose and glycerol. All strains reacted negative for $\alpha$-cyclodextrin, $\beta$-cyclodextrin, glycogen, inulin, mannan, $N$-acetyl D-glucosamine, $N$ acetyl D-mannosamine, amygdalin, L-arabinose, D-arabitol, cellobiose, L-fructose, D-galactose, D-galacturonic acid, gentiobiose, $m$-inositol, $\alpha$-D-lactose, lactulose, D-mannitol, D-melibiose, methyl $\alpha$-D-galactoside, methyl $\beta$-D-galactoside, D-raffinose, L-rhamnose, methyl $\alpha$-D-mannoside, sedoheptulosan, D-sorbitol, stachyose, D-tagatose, xylitol, $p$-hydroxyphenyl acetic acid, D-xylose, $\alpha$-ketoglutaric acid, lactamide, D-malic acid, D-alanine, $\mathrm{N}$-acetyl L-glutamic acid, L-alanine, glycyl L-glutamic acid, L-pyroglutamic acid, L-serine, adenosine, 2'-deoxyadenosine, inosine, thymidine, adenosine $5^{\prime}$-monophosphate, thymidine $5^{\prime}$-monophosphate, fructose 6-phosphate, glucose 1-phosphate, glucose 6-phosphate and DL- $\alpha$-glycerol phosphate.

\begin{tabular}{|c|c|c|c|c|c|}
\hline Compound & 1 & 2 & 3 & 4 & 5 \\
\hline Dextrin & + & + & - & - & - \\
\hline Tween 40 & - & - & + & + & + \\
\hline Tween 80 & - & - & + & + & + \\
\hline Arbutin & + & - & - & - & - \\
\hline D-Fructose & + & $\mathrm{W}$ & + & + & + \\
\hline D-Gluconic acid & - & - & + & - & - \\
\hline Maltose & + & + & - & - & - \\
\hline Maltotriose & + & + & - & - & - \\
\hline D-Mannose & + & + & $\mathrm{W}$ & + & + \\
\hline D-Melezitose & + & + & - & - & - \\
\hline 3-Methyl glucose & + & $\mathrm{W}$ & - & - & - \\
\hline Methyl $\alpha$-D-glucoside & + & + & - & - & - \\
\hline Methyl $\beta$-D-glucoside & + & + & - & - & - \\
\hline Palatinose & + & + & - & - & - \\
\hline D-Ribose & - & - & + & - & - \\
\hline Salicin & + & + & - & - & - \\
\hline Sucrose & + & + & - & - & - \\
\hline D-Trehalose & + & + & - & - & - \\
\hline Turanose & + & + & - & - & $\mathrm{w}$ \\
\hline Acetic acid & - & - & + & - & - \\
\hline$\alpha$-Hydroxybutyric acid & + & $\mathrm{w}$ & + & - & - \\
\hline$\beta$-Hydroxybutyric acid & - & - & + & - & - \\
\hline$\gamma$-Hydroxybutyric acid & - & - & + & - & - \\
\hline$\alpha$-Ketovaleric acid & - & - & + & - & - \\
\hline D-Lactic acid methyl ester & - & - & $\mathrm{W}$ & - & - \\
\hline L-Lactic acid & + & + & + & - & - \\
\hline L-Malic acid & - & - & + & - & - \\
\hline Methyl pyruvate & - & - & + & + & + \\
\hline Monomethyl succinate & - & - & + & $\mathrm{w}$ & $\mathrm{w}$ \\
\hline Propionic acid & - & - & $\mathrm{W}$ & - & - \\
\hline Pyruvic acid & - & - & + & - & + \\
\hline Succinamic acid & - & - & $\mathrm{w}$ & - & - \\
\hline Succinic acid & - & - & $\mathrm{w}$ & - & - \\
\hline Alaninamide & - & - & $\mathrm{W}$ & - & - \\
\hline L-Alanyl glycine & - & - & - & + & + \\
\hline L-Asparagine & - & - & + & - & - \\
\hline L-Glutamic acid & - & - & $\mathrm{w}$ & $\mathrm{W}$ & $\mathrm{w}$ \\
\hline Putrescine & - & - & + & + & + \\
\hline 2,3-Butanediol & - & - & $\mathrm{w}$ & - & - \\
\hline Uridine & - & - & - & + & - \\
\hline Uridine $5^{\prime}$-monophosphate & - & - & - & $\mathrm{W}$ & - \\
\hline
\end{tabular}


Table 3. Differential characteristics of Rhodococcus baikonurensis sp. nov. $A 1-22^{\top}$ and closely related Rhodococcus species

Strains: 1, Rhodococcus baikonurensis A1-22 $2^{\mathrm{T}} ; 2$, Rhodococcus erythropolis JCM 3201 ${ }^{\mathrm{T}}$; 3, Rhodococcus fascians DSM 20669 ${ }^{\mathrm{T}}$; 4 , Rhodococcus globerulus JCM $14531^{\mathrm{T}}$; 5, Rhodococcus opacus DSM 43205 ${ }^{\mathrm{T}} ; 6$, Rhodococcus percolatus MBS1 $1^{\mathrm{T}} ; 7$, Rhodococcus marinonascens DSM $43752^{\mathrm{T}}$. Data were taken from this study, Yoon et al. (2000), Klatte et al. (1994) and Briglia et al. (1996). W, Weakly positive.

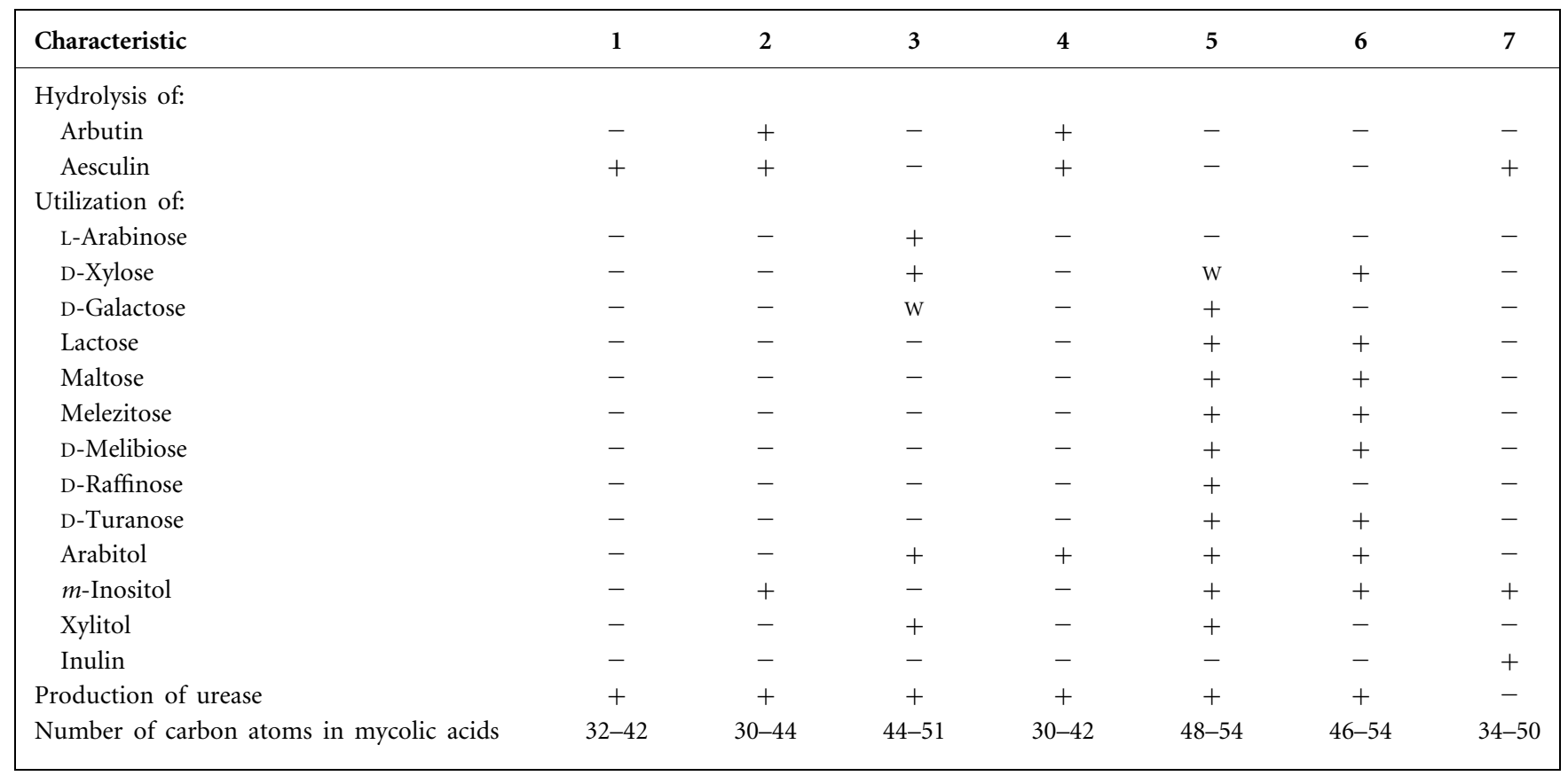

Arthrobacter. A tree constructed using the neighbourjoining method depicting the phylogenetic position of strains $\mathrm{A} 1-3^{\mathrm{T}}$ and A1-8 (Fig. 1) showed that strains A1-3 and A1-8 were closely related to Arthrobacter polychromogenes, Arthrobacter oxydans and Arthrobacter psychrolactophilus, with respective $16 \mathrm{~S}$ sequence similarity of $96 \cdot 6,96 \cdot 5$ and $95.5 \%$ (Table 4 ). $16 \mathrm{~S}$ rDNA sequence similarity values to members of other genera were less than $95 \%$. Strains A1- $3^{\mathrm{T}}$ and A1-8 exhibited an extremely high 16S rDNA sequence similarity of $99 \cdot 9 \%$. These results clearly demonstrated that strains $A 1-3^{\mathrm{T}}$ and A1-8 belong to the genus Arthrobacter.

Phenotypic and biochemical characteristics of strains A1-3 ${ }^{\mathrm{T}}$ and A1-8 (see species description) were consistent with the description of the genus Arthrobacter (Keddie et al., 1986). However, strains $\mathrm{A} 1-3^{\mathrm{T}}$ and A1-8 can be differentiated biochemically from closely related species of the genus Arthrobacter (Table 4). The metabolic properties determined from the Biolog GP2 assay are shown in Table 2.

The cellular fatty acid content of strain $\mathrm{A} 1-3^{\mathrm{T}}$ was as follows (only values $\geqslant 1 \%$ reported): iso-15:0 (13-methyl-14:0), $1 \%$; anteiso-15:0 (12-methyl-14:0), 20\%; iso-16:0 (14methyl-15:0), $4 \%$; $16: 0,2 \%$; iso-17:0 (15-methyl-16:0), $1 \%$; anteiso-17:0 (14-methyl-16:0), 64\%; anteiso-19:0 (16-methyl-18:0), 2\%; 2-OH 14:0, 1\%; and 2-OH 16:0, $4 \%$. This composition was consistent with that of members of the genus Arthrobacter, with anteiso-15:0 predominating. However, unlike many Arthrobacter species, including
A. oxydans, Arthrobacter agilis and Arthrobacter roseus (Reddy et al., 2002; Kodama et al., 1992), strain A1-3 ${ }^{\mathrm{T}}$ contained anteiso-19:0, 2-OH 14:0 and 2-OH 16:0. The predominant polar lipids were cardiolipin and phosphatidylinositol, with phosphatidylglycerol as a minor component. This composition is consistent with that of related species of the genus Arthrobacter (Reddy et al., 2002). Strains A1- $3^{\mathrm{T}}$ and A1-8 lack diaminopimelic acid in their cell walls. The amino acids glutamic acid, alanine and lysine were detected in a molar ratio of $1: 4: 1$ in the peptidoglycan. These results suggest that the interpeptide contains alanine and the peptidoglycan is A3 $\alpha$-type (Kodama et al., 1992; Fiedler et al., 1973), consistent with the peptidoglycan type found in species of the $A$. polychromogenes group (Koch et al., 1995). The predominant isoprenoid quinone was $\operatorname{MK}-9\left(\mathrm{H}_{2}\right)$.

Strains $\mathrm{A} 1-3^{\mathrm{T}}$ and A1-8 share DNA-DNA relatedness of $100 \%$, whereas these two strains showed only $9 \cdot 8 \%$ DNADNA relatedness with the nearest neighbour, A. polychromogenes. DNA-DNA hybridization is thought to be the superior method for the determination of relationships between bacteria (Stackebrandt \& Goebel, 1994). These results demonstrate that strains $A 1-3^{\mathrm{T}}$ and $\mathrm{A} 1-8$ belong to the same genetic species, which is independent of the established species of the genus Arthrobacter.

Phenotypic and chemotaxonomic characteristics of strains A1- $3^{\mathrm{T}}$ and A1-8 were also consistent with the description of the genus Arthrobacter and support the conclusion from 
Table 4. Differential characteristics of Arthrobacter russicus sp. nov. strains $\mathrm{A} 1-3^{\top}$ and $\mathrm{A} 1-8$ and closely related Arthrobacter species

Strains: 1, A. russicus strains A1-3 ${ }^{\mathrm{T}}$ and A1-8; 2, A. agilis CCM 2390 ${ }^{\mathrm{T}}$; 3, A. polychromogenes DSM 20136 ${ }^{\mathrm{T}}$; 4, A. psychrolactophilus ATCC $700733^{\mathrm{T}}$; 5, A. crystallopoietes ATCC $15481^{\mathrm{T}} ; 6$, A. oxydans ATCC $14358^{\mathrm{T}}$; 7 , A. roseus DSM $14508^{\mathrm{T}}$. Data were taken from this study, Loveland-Curtze et al. (1999), Funke et al. (1996) and Reddy et al. (2002). NA, Data not available; W, weakly positive.

\begin{tabular}{|c|c|c|c|c|c|c|c|}
\hline Characteristic & 1 & 2 & 3 & 4 & 5 & 6 & 7 \\
\hline Colony colour & Cream/white & Red & Blue/green & Yellow & White & Grey/white & Red \\
\hline \multicolumn{8}{|l|}{ Hydrolysis of: } \\
\hline Tween 80 & + & - & - & NA & NA & NA & $\mathrm{NA}$ \\
\hline Urease activity & - & - & - & - & + & + & - \\
\hline Inositol & - & - & - & $\mathrm{NA}$ & + & + & - \\
\hline Sorbitol & - & + & - & + & - & + & + \\
\hline Lactose & - & - & + & + & - & + & + \\
\hline Xylitol & - & - & - & NA & - & + & $\mathrm{NA}$ \\
\hline Xylose & - & - & - & + & - & + & + \\
\hline Growth at $37^{\circ} \mathrm{C}$ & - & - & + & - & NA & + & - \\
\hline $\begin{array}{l}\text { 16S rDNA sequence similarity } \\
(\%) \text { to strain } \mathrm{A} 1-3^{\mathrm{T}}\end{array}$ & $99 \cdot 9^{*}$ & 95 & $96 \cdot 6$ & 96 & $95 \cdot 5$ & $96 \cdot 5$ & $95 \cdot 3$ \\
\hline Peptidoglycan type & Lys-Ala 2 & Lys-Thr-Ala 3 & Lys-Ser-Thr-Ala & Lys-Ala $_{3}$ & Lys-Ala & Lys-Ser-Thr-Ala & Lys-Gly-Ala 3 \\
\hline
\end{tabular}

${ }^{*}$ Similarity between sequences of strains $\mathrm{A} 1-3^{\mathrm{T}}$ and $\mathrm{A} 1-8$.

the 16S rRNA alignment that these two strains belong to the genus Arthrobacter. However, biochemical characteristics and cellular fatty acid composition and DNA hybridization data sharply differentiate them from the closely related species $A$. polychromogenes. Therefore, the name Arthrobacter russicus sp. nov. is proposed for this species.

\section{Description of Rothia aeria sp. nov.}

Rothia aeria (aer'i.a. L. fem. adj. aeria of the air, referring to the isolation of the type strain from the air inside the Mir space station).

Grows well under aerobic conditions at $30{ }^{\circ} \mathrm{C}$ on $\mathrm{BHI}$ agar plates. Gram-positive cells appear coccoid, cocco-bacillary or filamentous. Young colonies are creamy white and smooth. Mature colonies are rough, dry, folded and convex and adhere to the agar medium such that they are not easily scraped off. Biochemical characteristics are summarized in Tables 1 and 2. Cell-wall peptidoglycan is A3 $\alpha$-type. Predominant isoprenoid quinone is MK-7. Major cellular fatty acids are anteiso-15:0 (12-methyl-14:0), iso-16:0 (14methyl-15:0) and anteiso-17:0 (14-methyl-18:0). Major polar lipids are phosphatidylglycerol and cardiolipin. The $\mathrm{G}+\mathrm{C}$ content of the type strain is $57 \cdot 8 \mathrm{~mol} \%$.
The type strain, A1-17B ${ }^{\mathrm{T}}\left(=\mathrm{GTC} 867^{\mathrm{T}}=\mathrm{JCM} 11412^{\mathrm{T}}=\right.$ DSM $14556^{\mathrm{T}}$ ), was isolated from an air sample from the Russian space station Mir. This species includes strains formerly categorized as Rothia dentocariosa genomovar II.

\section{Description of Rhodococcus baikonurensis sp. nov.}

Rhodococcus baikonurensis (bai.kon.ur.en'sis. N.L. masc. adj. baikonurensis of Baikonur, the town in Kazakhstan where the Mir space station was launched).

Grows well under aerobic conditions at $30^{\circ} \mathrm{C}$ on $\mathrm{BHI}$ agar plates. A mixture of Gram-positive rods and cocci show elementary branching. Colonies are smooth, opaque and slightly pink. Biochemical characteristics are summarized in Tables 2 and 3. Diamino acid in the peptidoglycan is meso-diaminopimelic acid. Cell-wall peptidoglycan is A $1 \gamma$ type. Predominant isoprenoid quinone is $\mathrm{MK}-8\left(\mathrm{H}_{2}\right)$. Major cellular fatty acids are 16:0, cis-18:1 and tuberculostearic acid (10-methyl-18:0). Mycolic acids contain 46-54 carbon atoms. Phospholipid composition is phosphatidylethanolamine, cardiolipin, phosphatidylinositol and phosphatidylinositol mannosides. The $\mathrm{G}+\mathrm{C}$ content of the type strain is $55 \cdot 5 \mathrm{~mol} \%$. 
The type strain, A1-22 ${ }^{\mathrm{T}}\left(=\mathrm{GTC} 1041^{\mathrm{T}}=\mathrm{JCM} 11411^{\mathrm{T}}=\right.$ DSM $44587^{\mathrm{T}}$ ), was isolated from an air sample from the Russian space station Mir.

\section{Description of Arthrobacter russicus sp. nov.}

Arthrobacter russicus [rus'sic.us. L. masc. adj. russicus pertaining to Russia (Russian space station)].

Grows well under aerobic conditions at $30^{\circ} \mathrm{C}$ on $\mathrm{BHI}$ agar plates, but unable to grow at $37^{\circ} \mathrm{C}$. Gram-positive, nonmotile, irregular rods, about $1 \cdot 3-3 \cdot 6 \mu \mathrm{m}$ long and $0 \cdot 5-$ $0.9 \mu \mathrm{m}$ wide. Circular, smooth and creamy colonies grow to a diameter of about $1.5 \mathrm{~mm}$ after $24 \mathrm{~h}$. Biochemical characteristics are summarized in Tables 2 and 4. Cellwall peptidoglycan is A $3 \alpha$-type. Predominant isoprenoid quinone is $\mathrm{MK}-9\left(\mathrm{H}_{2}\right)$. Major cellular fatty acids are anteiso15:0 (12-methyl-14:0) and anteiso-17:0 (14-methyl16:0). Predominant polar lipids are cardiolipin and phosphatidylinositol. The $\mathrm{G}+\mathrm{C}$ content of the type strain is $65.5 \mathrm{~mol} \%$.

The type strain, A1- $3^{\mathrm{T}}\left(=\mathrm{GTC} 863^{\mathrm{T}}=\mathrm{JCM} 11414^{\mathrm{T}}=\mathrm{DSM}\right.$ $\left.14555^{\mathrm{T}}\right)$, was isolated from an air sample from the Russian space station Mir.

\section{ACKNOWLEDGEMENTS}

This work was supported by the first Japanese and Russian collaboration on the Mir Utilization Project and a grant from the Japan Space Utilization Promotion Center (JSUP).

\section{REFERENCES}

Bergan, T. \& Kocur, M. (1982). Stomatococcus mucilaginosus gen. nov., sp. nov., ep. rev., a member of the family Micrococcaceae. Int J Syst Bacteriol 32, 374-377.

Briglia, M., Rainey, F. A., Stackebrandt, E., Schraa, G. \& SalkinojaSalonen, M. S. (1996). Rhodococcus percolatus sp. nov., a bacterium degrading 2,4,6-trichlorophenol. Int J Syst Bacteriol 46, 23-30.

Collins, M. D., Pirouz, T., Goodfellow, M. \& Minnikin, D. E. (1977). Distribution of menaquinones in actinomycetes and corynebacteria. J Gen Microbiol 100, 221-230.

Collins, M. D., Hutson, R. A., Båverud, V. \& Falsen, E. (2000). Characterization of a Rothia-like organism from a mouse: description of Rothia nasimurium sp. nov. and reclassification of Stomatococcus mucilaginosus as Rothia mucilaginosa comb. nov. Int J Syst Evol Microbiol 50, 1247-1251.

Criswell-Hudak, B. S. (1991). Immune response during space flight. Exp Gerontol 26, 289-296.

Decelle, J. G. \& Taylor, G. R. (1976). Autoflora in the upper respiratory tract of Apollo astronauts. Appl Environ Microbiol 32, 659-665.

Ezaki, T., Hashimoto, Y., Takeuchi, N., Yamamoto, H., Liu, S. L., Miura, H., Matsui, K. \& Yabuuchi, E. (1988). Simple genetic method to identify viridans group streptococci by colorimetric dot hybridization and fluorometric hybridization in microdilution wells. J Clin Microbiol 26, 1708-1713.

Ezaki, T., Hashimoto, Y. \& Yabuuchi, E. (1989). Fluorometric deoxyribonucleic acid-deoxyribonucleic acid hybridization in microdilution wells as an alternative to membrane filter hybridization in which radioisotopes are used to determine genetic relatedness among bacterial strains. Int J Syst Bacteriol 39, 224-229.

Ezaki, T., Saidi, S. M., Liu, S. L., Hashimoto, Y., Yamamoto, H. \& Yabuuchi, E. (1990). Rapid procedure to determine the DNA base composition from small amounts of gram-positive bacteria. FEMS Microbiol Lett 55, 127-130.

Ezaki, T., Li, N., Hashimoto, Y., Miura, H. \& Yamamoto, H. (1994). 16S Ribosomal DNA sequences of anaerobic cocci and proposal of Ruminococcus hansenii comb. nov. and Ruminococcus productus comb. nov. Int J Syst Bacteriol 44, 130-136.

Fan, Y., Jin, Z., Tong, J., Li, W., Pasciak, M., Gamian, A., Liu, Z. \& Huang, Y. (2002). Rothia amarae sp. nov., from sludge of a foul water sewer. Int J Syst Evol Microbiol 52, 2257-2260.

Fiedler, F., Schleifer, K. \& Kandler, O. (1973). Amino acid sequence of the threonine-containing mureins of coryneform bacteria. J Bacteriol 113, 8-17.

Fotos, P. G., Gerencser, M. A. \& Yelton, D. B. (1984). Strain differentiation of Rothia dentocariosa and related isolates by sodium dodecyl sulfate-polyacrylamide gel electrophoresis. Int J Syst Bacteriol 34, 102-106.

Funke, G., Hutson, R. A., Bernard, K. A., Pfyffer, G. E., Wauters, G. \& Collins, M. D. (1996). Isolation of Arthrobacter spp. from clinical specimens and description of Arthrobacter cumminsii sp. nov. and Arthrobacter woluwensis sp. nov. J Clin Microbiol 34, 2356-2363.

Georg, L. K. \& Brown, J. M. (1967). Rothia, gen. nov., an aerobic genus of the family Actinomycetaceae. Int J Syst Bacteriol 17, 79-88.

Gerencser, M. A. \& Bowden, G. H. (1986). Genus Rothia Georg and Brown 1967, 68 ${ }^{\mathrm{AL}}$. In Bergey's Manual of Systematic Bacteriology, vol. 2, pp. 1342-1346. Edited by P. H. A. Sneath, N. S. Mair, M. E. Sharpe \& J. G. Holt. Baltimore: Williams \& Wilkins.

Goodfellow, M. (1984). Reclassification of Corynebacterium fascians (Tilford) Dowson in the genus Rhodococcus, as Rhodococcus fascians comb. nov. Syst Appl Microbiol 5, 225-229.

Goodfellow, M. (1986). Genus Rhodococcus Zopf 1891, 28 ${ }^{\mathrm{AL}}$. In Bergey's Manual of Systematic Bacteriology, vol. 2, pp. 1472-1481. Edited by P. H. A. Sneath, N. S. Mair, M. E. Sharpe \& J. G. Holt. Baltimore: Williams \& Wilkins.

Goodfellow, M. (1992). The family Nocardiaceae. In The Prokaryotes, 2nd edn, vol. 2, pp. 1188-1213. Edited by A. Balows, H. G. Trüper, M. Dworkin, W. Harder \& K.-H. Schleifer. New York: Springer.

Grimont, P. A. D. (1999). Taxonomy and classification of bacteria. In Manual of Clinical Microbiology, 7th edn, pp. 249-259. Edited by P. R. Murray, E. J. Baron, M. A. Pfaller, F. C. Tenover \& R. H. Yolken. Washington, DC: American Society for Microbiology.

Kawamura, Y., Hou, X.-G., Sultana, F., Liu, S., Yamamoto, H. \& Ezaki, T. (1995). Transfer of Streptococcus adjacens and Streptococcus defectivus to Abiotrophia gen. nov. as Abiotrophia adiacens comb. nov. and Abiotrophia defectiva comb. nov., respectively. Int J Syst Bacteriol 45, 798-803.

Kawamura, Y., Li, Y., Liu, H., Huang, X., Li, Z. \& Ezaki, T. (2001). Bacterial population in Russian space station "Mir". Microbiol Immunol 45, 819-828.

Keddie, R. M., Collins, M. D. \& Jones, D. (1986). Genus Arthrobacter Conn and Dimmick 1947, 300 ${ }^{\mathrm{AL}}$. In Bergey's Manual of Systematic Bacteriology, vol. 2, pp. 1288-1301. Edited by P. H. A. Sneath, N. S. Mair, M. E. Sharpe \& J. G. Holt. Baltimore: Williams \& Wilkins.

Klatte, S., Kroppenstedt, R. M. \& Rainey, F. A. (1994). Rhodococcus opacus sp. nov., an unusual nutritionally versatile Rhodococcusspecies. Syst Appl Microbiol 17, 355-360.

Koch, C., Schumann, P. \& Stackebrandt, E. (1995). Reclassification of Micrococcus agilis (Ali-Cohen 1889) to the genus Arthrobacter as 
Arthrobacter agilis comb. nov. and emendation of the genus Arthrobacter. Int J Syst Bacteriol 45, 837-839.

Kodama, Y., Yamamoto, H., Amano, N. \& Amachi, T. (1992). Reclassification of two strains of Arthrobacter oxydans and proposal of Arthrobacter nicotinovorans sp. nov. Int J Syst Bacteriol 42, 234-239.

Komagata, K. \& Suzuki, K. (1987). Lipid and cell-wall analysis in bacterial systematics. Methods Microbiol 19, 161-207.

Kosako, Y., Yabuuchi, E., Naka, T., Fujiwara, N. \& Kobayashi, K. (2000). Proposal of Sphingomonadaceae fam. nov., consisting of Sphingomonas Yabuuchi et al. 1990, Erythrobacter Shiba and Shimidu 1982, Erythromicrobium Yurkov et al. 1994, Porphyrobacter Fuerst et al. 1993, Zymomonas Kluyver and van Niel 1936, and Sandaracinobacter Yurkov et al. 1997, with the type genus Sphingomonas Yabuuchi et al. 1990. Microbiol Immunol 44, 563-575.

Kronvall, G., Lannér-Sjöberg, M., von Stedingk, L. V., Hanson, H. S., Pettersson, B. \& Falsen, E. (1998). Whole cell protein and partial $16 \mathrm{~S}$ rRNA gene sequence analysis suggest the existence of a second Rothia species. Clin Microbiol Infect 4, 255-263.

Lesher, R. J., Gerencser, M. A. \& Gerencser, V. F. (1974). Morphological, biochemical, and serological characterization of Rothia dentocariosa. Int J Syst Bacteriol 24, 154-159.

Li, Y., Kawamura, Y., Fujiwara, N., Naka, T., Liu, H., Huang, X., Kobayashi, K. \& Ezaki, T. (2003). Chryseobacterium miricola sp. nov., a novel species isolated from condensation water of space station Mir. Syst Appl Microbiol 26, 523-528.

Li, Y., Kawamura, Y., Fujiwara, N., Naka, T., Liu, H., Huang, X., Kobayashi, K. \& Ezaki, T. (2004). Sphingomonas yabuuchiae sp. nov. and Brevundimonas nasdae sp. nov., isolated from the Russian space laboratory Mir. Int J Syst Evol Microbiol 54, 819-825.

Loveland-Curtze, J., Sheridan, P. P., Gutshall, K. R. \& Brenchley, J. E. (1999). Biochemical and phylogenetic analyses of psychrophilic isolates belonging to the Arthrobacter subgroup and description of Arthrobacter psychrolactophilus sp. nov. Arch Microbiol 171, 355-363.

Minnikin, D. E., O'Donnell, A. G., Goodfellow, M., Alderson, G., Athalye, M., Schaal, A. \& Parlett, J. H. (1984). An integrated procedure for extraction of bacterial isoprenoid quinones and polar lipids. J Microbiol Methods 2, 233-241.

Neidhardt, F. C. (1990). The bacterial cell: structures for growth, survival, and colonization. In Medical Microbiology, 2nd edn, pp. 11-26. Edited by J. C. Sherris, J. J. Champoux, L. Corey, F. C. Neidhardt, J. J. Plorde, C. G. Ray \& K. J. Ryan. New York: Elsevier.
Nishiuchi, Y., Baba, T., Hotta, H. H. \& Yano, I. (1999). Mycolic acid analysis in Nocardia species. The mycolic acid compositions of Nocardia asteroides, N. farcinica, and N. nova. J Microbiol Methods 37, 111-122.

Page, R. D. M. (1996). TREEVIEW: an application to display phylogenetic trees on personal computers. Comput Appl Biosci 12, 357-358.

Pearson, W. R. \& Lipman, D. J. (1988). Improved tools for biological sequence comparison. Proc Natl Acad Sci U S A 85, 2444-2448.

Reddy, G. S. N., Prakash, J. S. S., Matsumoto, G. I., Stackebrandt, E. \& Shivaji, S. (2002). Arthrobacter roseus sp. nov., a psychrophilic bacterium isolated from an Antarctic cyanobacterial mat sample. Int J Syst Evol Microbiol 52, 1017-1021.

Saitou, N. \& Nei, M. (1987). The neighbor-joining method: a new method for reconstructing phylogenetic trees. Mol Biol Evol 4, 406-425.

Schleifer, K. H. \& Kandler, O. (1972). Peptidoglycan types of bacterial cell walls and their taxonomic implications. Bacteriol Rev 36, 407-477.

Schofield, G. M. \& Schaal, K. P. (1981). A numerical taxonomic study of members of the Actinomycetaceae and related taxa. J Gen Microbiol 127, 237-259.

Stackebrandt, E. \& Goebel, B. M. (1994). Taxonomic note: a place for DNA-DNA reassociation and 16S rRNA sequence analysis in the present species definition in bacteriology. Int J Syst Bacteriol 44, 846-849.

Thompson, J. D., Higgins, D. G. \& Gibson, T. J. (1994). CLUSTAL W: improving the sensitivity of progressive multiple sequence alignment through sequence weighting, position-specific gap penalties and weight matrix choice. Nucleic Acids Res 22, 4673-4680.

Wayne, L. G., Brenner, D. J., Colwell, R. R. \& 9 other authors (1987). Report of the ad hoc committee on reconciliation of approaches to bacterial systematics. Int J Syst Bacteriol 37, 463-464.

Yano, I., Yamada, Y. \& Suzuki, K. I. (1987). Analysis of bacterial ingredients. In Bacterial Identification in Accordance with Recent Taxonomy: Use of Phenotypic, Chemical, and Genetic Analysis, pp. 41-85. Edited by E. Yabuuchi, T. Ezaki, Y. H. Park, H. Sugawara, K. I. Suzuki, Y. Yamada, H. Yamanoto \& I. Yano. Tokyo: Saikon Publications.

Yoon, J.-H., Cho, Y.-G., Kang, S.-S., Kim, S. B., Lee, S. T. \& Park, Y.-H. (2000). Rhodococcus koreensis sp. nov., a 2,4-dinitrophenoldegrading bacterium. Int J Syst Evol Microbiol 50, 1193-1201. 